\title{
A novel therapy with testosterone and sildenafil for erectile dysfunction in patients on renal dialysis or after renal transplantation
}

\author{
Ratna Chatterjee, PhD, MFF, Departments of Obstetrics and Gynaecology; Susan Wood, BSc, Department of Nephrology; \\ Hugh H McGarrigle, PhD, Departments of Obstetrics and Gynaecology; William R Lees, FRCR, Department of Nuclear \\ Medicine and Radiology; David J Ralph, FRCS, MSc, Institute of Urology and Nephrology; Guy H Neild, FRCP, MD, Institute \\ of Urology and Nephrology, University College Hospitals, London, UK
}

Correspondence: Dr Ratna Chatterjee, University College Hospital, Reproductive Medicine Unit, Huntley Street, London WC1E 6AU, UK. Fax: +44 (0) 207380 9600. E-mail: rchatterjee1@aol.com

(Accepted 2 February 2004)

Journal of Family Planning and Reproductive Health Care 2004; 30(2): 88-90

\begin{abstract}
Background We undertook a prospective pilot study in a small cohort of patients with renal replacement therapy to determine the cause of erectile dysfunction (ED) and evaluate the role of testosterone replacement therapy and sildenafil.

Methods We investigated 12 patients (eight post-transplant and four on haemodialysis) who presented with ED for hypogonadism and cavernosal insufficiency. We assessed sexual performance before and after treatment by a questionnaire method based on the modified International Index of Erectile Function (IIEF) and National Institutes of Health (NIH) rating. Patients received $250 \mathrm{mg}$ intramuscular monthly injections of testosterone cypionate and 50-100 mg sildenafil orally once or twice weekly for 12 months. Therapeutic response was considered good if the patient could maintain an erection adequate for successful sexual intercourse (NIH criteria) and had a marked improvement in the overall sexual performance (IIEF scoring).

Results Before treatment all patients had severe ED with a poor IIEF score while 11 also had diminished libido. Eleven patients had diminished testicular volume and six had elevated follicle-stimulating hormone levels suggestive of germ cell damage. All patients had a good response to the therapeutic trial of testosterone and sildenafil.

Conclusions Therapy with testosterone and sildenafil may be indicated for those with both cavernosal arterial insufficiency and reproductive hormone abnormalities. Further longer-term data are needed to determine the safety and efficacy of this novel regimen.
\end{abstract}

\section{Key message points}

- Patients with erectile dysfunction (ED) who were receiving dialysis or had renal transplantation were shown to have cavernosal arteriogenic insufficiency and abnormal reproductive hormone profiles.

- Investigations to determine the aetiology of ED may help to guide therapeutic options.

- Therapy with sildenafil and testosterone should be considered in patients who have cavernosal arteriogenic insufficiency and abnormal reproductive hormone profiles. Patients receiving immunosuppressant drugs require monitoring as they are at higher risk of the carcinogenic and other side effects of testosterone.

\section{Introduction}

Erectile dysfunction (ED) affects $40-100 \%$ of men on renal replacement therapy, including dialysis and transplantation. ${ }^{1,2}$ The aetiology is usually multifactorial. The main organic factors are primary ${ }^{3,4}$ or secondary hypogonadism (hypothalamic pituitary dysfunction, hyperprolactinaemia) and penile arterial insufficiency. 5

Previous attempts at therapy have included intracavernosal injections of vasoactive agents, such as alphaprostil, papaverine ${ }^{6,7}$ or penile prosthesis. ${ }^{8}$ All are associated with poor results due to poor tolerance, prosthetic infection and cylinder leak. ${ }^{9}$ The use of the oral agent, type 5 phosphodiesterase inhibitor, sildenafil citrate, has been used successfully in patients on renal dialysis ${ }^{10}$ and after renal transplantion. ${ }^{11}$

Vasoactive drugs, however, may fail to correct sexual dysfunction if libido is also affected. Patients with renal transplant and dialysis may have testosterone deficiency, which can cause reduced libido. ${ }^{2,3}$ Reports are conflicting on the value of testosterone in renal patients, especially as testosterone levels may return to normal in some patients after transplantation. ${ }^{2}$ However, patients may have normal testosterone levels with diminished Leydig cell reserve, which can contribute to symptoms of androgen insufficiency including diminished libido. ${ }^{12}$ Other advantages of testosterone include its potential cavernosal vasodilator activity. ${ }^{13}$ A meta-analysis of studies confirms the beneficial effects of testosterone supplementation in patients with ED. ${ }^{14}$ A similar improvement is expected in patients with renal replacement, especially if they have hypogonadism.

We undertook a pilot study in a small cohort of patients with renal replacement or on dialysis to determine the cause of ED and to institute a trial of sildenafil and testosterone therapy, as this treatment had been successful in a group of patients with haematological malignancies. 15

\section{Methods}

We prospectively studied 12 patients over the period 1997-2001, who presented with ED, either after renal transplantation $(n=8)$ or while on haemodialysis $(n=4)$. Clinical data are given in Table 1 . All patients older than 50 years and those with a history of cardiovascular disease were screened for potential contraindications before treatment.

We assessed testicular function by measuring testicular volume (ultrasound and orchidometer). ${ }^{16}$ Hyperplasia or adenoma was excluded by prostatic ultrasound. All patients had an endocrine profile (Table 2). All hormones were assayed by standard radio-immunoassay using double antibody techniques. ${ }^{17}$ 


\begin{tabular}{|c|c|c|c|c|c|c|c|c|}
\hline \multirow[t]{2}{*}{ Patient } & \multirow{2}{*}{$\begin{array}{l}\text { Age } \\
\text { (years) }\end{array}$} & \multirow[t]{2}{*}{ Primary renal diagnosis } & \multirow[t]{2}{*}{ Other characteristics } & \multirow[t]{2}{*}{ RRT } & \multicolumn{4}{|c|}{ Sexual dysfunction } \\
\hline & & & & & Duration (years) & ED grade & Libido & Ejaculation \\
\hline 1 & 40 & IDDM & $\begin{array}{l}\text { Retinopathy, porphyria, } \\
\text { peripheral vascular disease, } \\
\text { osteoporosis }\end{array}$ & CRT & 4 & I & Diminished & Normal \\
\hline 2 & 29 & Prune belly syndrome & $\begin{array}{l}\text { Left orchidectomy, IDDM, } \\
\text { Peyronie's disease }\end{array}$ & LRT & 2 & I & Diminished & Aejaculation \\
\hline 3 & 44 & Amyloid & $\begin{array}{l}\text { Bilateral hip and knee } \\
\text { arthroplasty, osteoporosis }\end{array}$ & HD & 1 & I & Diminished & Aejaculation \\
\hline 4 & 56 & Polycystic kidney & $\begin{array}{l}\text { Mild ischaemic heart disease, } \\
\text { Still's disease }\end{array}$ & CRT & 3 & I & Diminished & Normal \\
\hline 5 & 39 & Prune belly syndrome & $\begin{array}{l}\text { Gout, duodenal ulcer, morbid } \\
\text { obesity, orchidopexy }\end{array}$ & CRT & 4 & I & Diminished & Aejaculation \\
\hline 6 & 43 & Hypertension & $\begin{array}{l}\text { Hyperaldosteronism, } \\
\text { adrenalectomy }\end{array}$ & $\mathrm{CRT}^{*}$ & 1 & I & Diminished & Normal \\
\hline 7 & 27 & Obstructive uropathy & $\begin{array}{l}\text { Cytomegalovirus, chronic } \\
\text { active hepatitis, positive } \\
\text { hepatitis C }\end{array}$ & HD* & 2 & I & Diminished & Normal \\
\hline 8 & 48 & IDDM & Retinopathy, neuropathy & CRT & 1 & $\mathrm{I}$ & Diminished & Normal \\
\hline 9 & 51 & Chronic glomerulonephritis & Mild ischaemic heart disease & CRT & 2 & I & Diminished & Normal \\
\hline 10 & 49 & Obstructive uropathy & & HD & 1 & $\mathrm{I}$ & Diminished & Normal \\
\hline 11 & 33 & IDDM & Retinopathy, neuropathy & HD & 1 & $\mathrm{I}$ & Normal & Painful \\
\hline 12 & 45 & Chronic glomerulonephritis & & CRT & 2 & II & Diminished & Premature \\
\hline
\end{tabular}

CRT, cadaveric renal transplant; CRT*, second transplant; ED, erectile dysfunction; HD, haemodialysis; HD*, failed transplant; IDDM, insulin-dependent diabetes mellitus; LRT, live related transplant; RRT, renal replacement therapy.

Colour flow Doppler was undertaken to assess haemodynamic function of the penis after injection of a vasoactive agent to induce an erection. ${ }^{18}$ The response to intracavernosal injection was graded as: $0=$ nil erection; I = tumescence only; II = partial and III = full rigidity according to our previously published data. 16

All patients had a therapeutic trial of 12 months of $250 \mathrm{mg}$ intramuscular monthly injections of testosterone cypionate and 50-100 mg sildenafil orally, once or twice weekly. Therapeutic response was considered good if the patient could maintain an erection adequate for successful sexual intercourse measured by the National Institute of Health (NIH) rating ${ }^{19}$ and International Index of Erectile Function (IIEF) scores. ${ }^{20}$ The regime was in accordance with our previously published data. ${ }^{15}$ All patients gave written informed consent to participate in this study as approved by the local research ethics committee of the University College London Hospitals Trust.

\section{Results}

Table 1 shows the clinical features and Table 2 the baseline endocrine and investigative data of the patients at the onset of the study. All transplant patients had renal transplantation at least 12 months before and had stable renal function for 6 months before and during the study period. No patients had contraindications to therapy. Only one patient (Patient 10) did not have diminished testicular volume and six had elevated follicle-stimulating hormone levels. While only two patients had low testosterone levels, others had a variety of reproductive hormone abnormalities (Table 2). All patients responded to treatment (Table 3). There were no adverse effects or deterioration of renal function and compliance was excellent.

Table 2 Endocrine and investigative data at the onset of the study

\begin{tabular}{|c|c|c|c|c|c|c|c|c|c|c|c|c|c|}
\hline \multirow[t]{2}{*}{ Patient } & \multicolumn{2}{|c|}{$\begin{array}{l}\text { Testicular volume } \\
(\mathrm{ml})\end{array}$} & \multirow{2}{*}{$\begin{array}{l}\text { Mean penile } \\
\text { Doppler flow } \\
\text { (PSV cm/ } \\
\text { second) }\end{array}$} & \multirow[t]{2}{*}{$\begin{array}{l}\text { FSH } \\
(\mathrm{IU} / \mathrm{l})\end{array}$} & \multirow[t]{2}{*}{$\begin{array}{l}\mathrm{LH} \\
(\mathrm{IU} / \mathrm{l})\end{array}$} & \multirow[t]{2}{*}{$\begin{array}{l}\text { Prolactin } \\
(\mathrm{mU} / \mathrm{l})\end{array}$} & \multirow[t]{2}{*}{$\begin{array}{l}\text { Testosterone } \\
(\mathrm{nmol} / \mathrm{l})\end{array}$} & \multirow{2}{*}{$\begin{array}{l}\text { Free } \\
\text { testosterone } \\
(\%)\end{array}$} & \multirow[t]{2}{*}{$\begin{array}{l}\mathrm{T} / \mathrm{LH} \\
\text { ratio }\end{array}$} & \multirow[t]{2}{*}{$\begin{array}{l}\text { SHBG } \\
(\mathrm{nmol} / \mathrm{l})\end{array}$} & \multirow{2}{*}{$\begin{array}{l}\text { Androste- } \\
\text { nedione } \\
(\mathrm{nmol} / \mathrm{l})\end{array}$} & \multirow[t]{2}{*}{$\begin{array}{l}\text { DHEAS } \\
(\mathrm{mmol} / \mathrm{l})\end{array}$} & \multirow[t]{2}{*}{$\begin{array}{l}\mathrm{E}_{2} \\
(\mathrm{pmol})\end{array}$} \\
\hline & Right & Left & & & & & & & & & & & \\
\hline 1 & 12.0 & 12.0 & 18 & 29.7 & 3.1 & 900 & 16.1 & 1.4 & 5.20 & 47.0 & 4.5 & 16.0 & 150 \\
\hline 2 & Absent & 10.0 & 7.0 & 38.8 & 16.0 & 1000 & 9.4 & 1.2 & 0.58 & 28.0 & 12.0 & 14.0 & 140 \\
\hline 3 & 3.0 & 3.0 & 25.0 & 19.4 & 12.4 & 100 & 10.8 & 1.8 & 0.88 & 23.0 & 6.0 & 8.0 & 40 \\
\hline 4 & 8.0 & 8.0 & 15.0 & 12.2 & 10.0 & 120 & 12.8 & 1.8 & 1.28 & 32.2 & 12.0 & 18.0 & 60 \\
\hline 5 & 5.5 & 3.8 & 6.5 & 10.6 & 16.8 & 90 & 11.9 & 1.4 & 0.71 & 20.0 & 10.0 & 14.0 & 70 \\
\hline 6 & 11.0 & 12.0 & 20.0 & 11.0 & 2.0 & 200 & 11.0 & 1.9 & 5.5 & 20.0 & 12.0 & 18.0 & 40 \\
\hline 7 & 14.0 & 14.0 & 18.0 & 5.5 & 5.6 & 800 & 25.8 & 1.8 & 4.61 & 30.0 & 20.0 & 12.0 & 120 \\
\hline 8 & 8.0 & 10.0 & 15.0 & 16.4 & 10.8 & 340 & 8.0 & 1.4 & 0.74 & 30.0 & 20.0 & 18.0 & 30 \\
\hline 9 & 8.0 & 8.0 & 20.0 & 12.2 & 18.2 & 300 & 7.9 & 1.8 & 0.43 & 28.0 & 18.0 & 12.0 & 60 \\
\hline 10 & 17.0 & 16.0 & 30.0 & 8.8 & 7.4 & 600 & 27.4 & 1.6 & 3.70 & 31.0 & 10.3 & 10.0 & 80 \\
\hline 11 & 8.0 & 8.0 & 18.0 & 18.0 & 12.0 & 400 & 9.8 & 1.2 & 0.82 & 30.0 & 10.0 & 18.0 & 100 \\
\hline 12 & 10.0 & 10.0 & 40 & 16.0 & 6.2 & 450 & 14.0 & 2.1 & 2.26 & 14.0 & 4.7 & 19.0 & 90 \\
\hline Range & $3-17$ & $3-16$ & $6.5-40$ & $1-38.8$ & $2-18.2$ & $120-1000$ & 13.75 & $1.2-2.1$ & $0.4-5.5$ & $14-47$ & $4.5-20$ & $8-19$ & $30-150$ \\
\hline Median & 8.0 & 10.0 & 18.0 & 14.1 & 10.4 & 370.0 & 11.45 & 1.7 & 1.1 & 29 & 11.15 & 15.0 & 75.0 \\
\hline $\begin{array}{l}\text { Normal } \\
\text { values }\end{array}$ & $15-25$ & & $>30$ & $2-12$ & $2-12$ & $0-620$ & $9-33$ & $\begin{array}{l}1.34 \text { to } \\
>2.4\end{array}$ & $2.75-4.5$ & $10-48$ & $4-10$ & $2-12$ & $30-300$ \\
\hline
\end{tabular}

DHEAS, dehydroepiandrosterone sulphate; E2, oestradiol; FSH, follicle-stimulating hormone; LH, luteinising hormone; PSV, peak systolic velocity; SHBG, sex hormone-binding globulin; $\mathrm{T}$, testosterone. 
Table 3 Endocrine and sexual function pretreatment vs post-treatment

\begin{tabular}{|c|c|c|c|c|c|c|}
\hline \multirow[t]{2}{*}{ Patient } & \multicolumn{3}{|c|}{ IIEF score } & \multicolumn{3}{|c|}{$\mathrm{NIH}$ rating } \\
\hline & $0 / 12$ & $6 / 12$ & $9 / 12$ & $0 / 12$ & $6 / 12$ & $9 / 12$ \\
\hline 1 & 23 & 65 & 66 & $\mathrm{P}$ & $\mathrm{S}$ & $S$ \\
\hline 2 & 16 & 69 & 65 & $\mathrm{P}$ & $\mathrm{S}$ & $\mathrm{S}$ \\
\hline 3 & 16 & 66 & 64 & $\mathrm{P}$ & $\mathrm{S}$ & $S$ \\
\hline 4 & 17 & 66 & 68 & $\mathrm{P}$ & $\mathrm{S}$ & $\mathrm{S}$ \\
\hline 5 & 20 & 65 & 66 & $\mathrm{P}$ & $\mathrm{S}$ & $S$ \\
\hline 6 & 22 & 66 & 68 & $\mathrm{P}$ & $\mathrm{S}$ & $\mathrm{S}$ \\
\hline 7 & 16 & 65 & 66 & $\mathrm{P}$ & $\mathrm{S}$ & $\mathrm{S}$ \\
\hline 8 & 18 & 64 & 66 & $\mathrm{P}$ & $\mathrm{S}$ & $\mathrm{S}$ \\
\hline 9 & 20 & 65 & 68 & $\mathrm{P}$ & $\mathrm{S}$ & $\mathrm{S}$ \\
\hline 10 & 23 & 65 & 65 & $\mathrm{P}$ & $\mathrm{S}$ & $\mathrm{S}$ \\
\hline 11 & 24 & 64 & 66 & $\mathrm{P}$ & $\mathrm{S}$ & $\mathrm{S}$ \\
\hline 12 & 25 & 60 & 62 & $\mathrm{P}$ & $\mathrm{S}$ & $\mathrm{S}$ \\
\hline Median & 20 & 65 & 66 & & & \\
\hline Range & $16-25$ & $60-69$ & $62-68$ & & & \\
\hline
\end{tabular}

IIEF, International Index of Erectile Function; NIH, National Institutes of Health; P, poor; S, satisfactory.

\section{Discussion}

We found reproductive hormonal abnormalities and cavernosal insufficiency in renal patients presenting with ED. We used combination therapy with testosterone and sildenafil successfully in these patients. We found a similar favourable outcome for erectile performance in cancer patients using the same therapeutic regimen. ${ }^{15}$ The main advantage of sildenafil is that it effectively treats ED, whatever the cause. This is relevant in renal diseases where multiple organic and psychogenic disorders are present. Although cardiac, retinal and vasomotor symptoms have been described with sildenafil, the adverse effects are infrequent and generally mild. ${ }^{21,22}$

Sildenafil monotherapy is likely to be less effective in patients who have diminished libido due to Leydig cell insufficiency. ${ }^{3}$ Since sildenafil only works on a sexually stimulated penis ${ }^{23}$ addition of testosterone can be synergistic. Testosterone can improve symptoms such as energy, drive and generalised symptoms of depression and fatigue. Some trials have shown the efficacy of testosterone in ED patients. ${ }^{13,24,25}$ Dual therapy with testosterone and sildenafil may be beneficial in this group of patients. We recommend selection of patients by excluding those with contraindications to either medication.

The mixed aetiology of ED in these patients suggests that similar patients with ED should have investigations to determine the aetiology of the condition. Therapy with testosterone and sildenafil may be indicated for those with both cavernosal arterial insufficiency and reproductive hormone abnormalities. We recommend long-term followup of these patients for cardiovascular effects, in addition to prostate specific antigen assays and prostatic ultrasound, ${ }^{26}$ as patients taking immunosuppressant drugs are at higher carcinogenic risk on testosterone. A prospective study using the above regime in a large sample size of patients on renal replacement therapy is currently underway.

\section{Acknowledgements}

The authors acknowledge members of the staff of the Departments of Reproductive Medicine, Nuclear Medicine and Radiology, Urology, and the Antrim and Mary Rankin Wards for their support in conducting the study.
Statements on funding and competing interests

Funding. None identified.

Competing interests. None identified.

References

1 Lawrence IG, Price DE, Howlett TA, et al. Correcting impotence in the male dialysis patient: testosterone replacement and vacuum tumescence. Am J Kidney Dis 1998; 2: 313-319.

2 Carsson CC, Patel MP. The epidemiology, anatomy, physiology, and treatment of erectile dysfunction in chronic renal failure patients. $A d v$ Ren Replace Ther 1999; 6: 296-309.

3 Burgos FJ, Pascual J, Gomez V, et al. Effect of kidney transplantation and cyclosporine treatment on male sexual performance and hormonal profile: a prospective study. Transplant Proc 1997; 29: 227.

4 Kaufman JM, Hatzichristou DG, Mulhall JP, et al. Impotence and chronic renal failure: a study of the haemodynamic pathophysiology. J Urol 1994; 151: 612-618.

5 Coppola A, Cuomo G. Pituitary-testicular evaluation in patients with chronic renal insufficiency in haemodialysis treatment. Minerva Med 1999; 81: 461.

6 Rodriguez Antolin A, Morales JM, Andres A, et al. Treatment of erectile impotence in renal transplant patients with intracavernosal vasoactive drugs. Transplant Proc 1992; 24: 105-106.

7 Mansi MK, Alkhudair WK, Huraib S. Treatment of erectile dysfunction after kidney transplantation with intracavernosal selfinjection of prostaglandin E1. J Urol 1998; 159: 1927-1930.

8 Ahuja SK, Krane NK, Hellstrom WJ. Penile prosthesis in the management of impotence in patients with end-stage renal disease. J La State Med Soc 1998; 150: 32-34.

9 Rowe SJ, Montague DK, Steinmuller DR, et al. Treatment of organic impotence with penile prosthesis in renal transplant patients. Urology 1993; 41: 16-20

10 Seibel I, Poli De Figueiredo CE, et al. Efficacy of oral sildenafil in hemodialysis patients with erectile dysfunction. J Am Soc Nephrol 2002; 13: 2770-2775

11 Barrou B, Cuzin B, Malavaud B, et al. Early experience with sildenafil for the treatment of erectile dysfunction in renal transplant recipients. Nephrol Dial Transplant 2003; 18: 411-417.

12 Chatterjee R, Kottaridis PD, HH McGarrigle, et al. Patterns of Leydig cell insufficiency in adult males, following bone marrow transplantation for haematological malignancies. Bone Marrow Transplant 2001; 28: 497-502.

13 Aversa A, Isidori AM, De Martino MU, et al. Androgens and penile erection: evidence for a direct relationship between free testosterone and cavernous vasodilatation in men with erectile dysfunction. Clin Endocrinol $(O x f)$ 2000; 53: 517-522.

14 Jain P, Rademaker AW, McVary KT. Testosterone supplementation for erectile dysfunction: results of a meta-analysis. J Urol 2000; 164: 371-375.

15 Chatterjee R, Kottaridis PD, McGarrigle HH, et al. Management of erectile dysfunction by combination therapy with testosterone and sildenafil in recipients of high-dose therapy for haematological malignancies. Bone Marrow Transplant 2002; 29: 607-610.

16 Chatterjee R, Kottaridis P D, Lees WR, et al. Cavernosal arterial insufficiency and erectile dysfunction in recipients of high-dose chemotherapy and total body irradiation for multiple myeloma. Lancet 2000; 355(9212):1335-1336.

17 Chatterjee R, Mills W, Katz M, et al. Germ cell failure and Leydig cell insufficiency in post-pubertal males after BEAM for lymphoma. Bone Marrow Transplant 1994; 13: 519-522.

18 Patel U, Amin Z, Friedman E, et al. Colour Doppler imaging in 220 men: the role of repeated sampling, velocity asymmetry and vascular anomalies. Clin Radiol 1993; 48: 18-24.

19 National Institutes of Health Consensus Statement. Impotence 1992; 7: 101-131.

20 Rosen RC. The International Index of Erectile Function (IIEF): multicentric scale for assessment of erectile dysfunction. Urology 1997; 49: 822-830.

21 Osterloh JH, Collins M, Wicker P, et al. Sildenafil citrate (Viagra): overall safety profile in 18 double blind, placebo controlled clinical trials. Int J Clin Pract Suppl 1999; 102: 3-5.

22 Goldstein I, Lue TF, Padma-Nathan H, et al. Oral sildenafil treatment of erectile dysfunction. $N$ Engl J Med 1998; 338: 1397-1404.

23 Lue TF. Erectile dysfunction. N Engl J Med 2000; 342: 1802-1813.

24 Levy A, Crowley T, Gingell C. Non-surgical management of erectile dysfunction. Clin Endocrinol $(O x f)$ 2000; 52: 253-260.

25 Nehra A. Treatment of endocrinologic male sexual dysfunction. Mayo Clin Proc 2000; 75(Suppl.): S40-S45

26 Hafez B. Recent advances in clinical/molecular andrology. Arch Androl 1998; 40:187-210. 